\title{
Transport of L-Cystine by Cultivated Skin Fibroblasts of Normal Subjects and Patients with Cystinosis
}

\author{
CELIA I. KAYE ${ }^{(29)}$ AND HENRY L. NADLER \\ Division of Genetics, Children's Memorial Hospital, Department of Pediatrics, Northwestern University Medical \\ School, Chicago, Illinois, USA
}

\section{Extract}

Uptake of L-cystine at the plasma membrane of fibroblasts derived from normal and cystinotic subjects was studied. L-Cystine accumulation after a 20 -min period was increased in cystinotic fibroblasts incubated in $0.08 \mathrm{mM}$ L-cystine. This effect appeared to be concentration-dependent since accumulation after $20 \mathrm{~min}$ at $0.004 \mathrm{mM}$ concentration was decreased in cystinotic cells. Kinetic data suggested that at least two nondiffusional saturable processes with widely different substrate affinities mediate initial L-cystine uptake in skin fibroblasts. In addition, the transport process with high affinity for L-cystine may itself be a two-component system, as suggested by $(l)$ additive inhibtory effect of other neutral amino acids, and (2) preincubation studies in which preincubation with cystathionine enhanced subsequent L-cystine uptake, whereas preincubation with other neutral amino acids depressed subsequent uptake. Affinity constants and maximal velocities of initial uptake did not appear to be altered in cells derived from patients with cystinosis. After 60 -sec incubation with $\mathrm{L}-\left[{ }^{35} \mathrm{~S}\right]$ cystine, cystinotic cells retained more label as cystine than did normal cells at each concentration studied.

These data indicate that initial L-cystine uptake in fibroblasts of patients with cystinosis proceeds at a normal rate by means of all transport systems currently shown to be present in normal cells.

\section{Speculation}

L-Cystine may accumulate in cells of patients with cystinosis because of an alteration in a transport system for L-cystine which is, as yet, undescribed. Alternatively, L-cystine accumulation may occur because of a transport defect at the lysosomal membrane which is not expressed at the plasma membrane.

Nephropathic cystinosis is a recessively inherited disorder characterized by lysosomal accumulation of L-cystine in celis of affected individuals (17). The nature of the biochemical defect in this disease has been the subject of much investigation. Since no enzymatic defect which might lead to L-cystine accumulation has been demonstrated $(8,20,21)$, a number of investigators have postulated that abnormal transport of L-cystine or L-cysteine at the plasma or lysosomal membrane may be responsible for the observed accumulation (17). Schneider et al. (15) demonstrated an increased uptake of L-cysteine in leukocytes of cystinotic subjects. In these studies, a rapid conversion of the labeled compound to L-cystine was noted, suggesting that the increased uptake may be a compensatory mechanism for maintaining the physiologic concentration of intracellular amino acid rather than a defect in transport at the plasma membrane. Schulman et al. (16) studied uptake of L-cystine in leukocytes growing in continuous culture from patients with cystinosis. The accumulation of L-cystine in cells of affected subjects was similar to controls over a 45 -min interval.
States et al. (18) investigated the uptake of exogenous L-cystine in fibroblasts of cystinotic and normal individuals over a concentration range of $0.05-0.125 \mathrm{mM}$. They concluded that the apparent $\mathrm{K}_{\mathrm{m}}$ for L-cystine uptake was similar in both cell types, although the cystinotic cells demonstrated a higher maximum velocity of entry. A decreased efflux of L-cystine from cystinotic cells was also noted. The purpose of the present investigation is to further clarify the mechanism of L-cystine uptake at the plasma membrane of fibroblasts derived from normal and cystinotic subjects.

\section{MATERIALS AND METHODS}

\section{FIBROBLAST CULTURE}

Skin biopsies were obtained with informed consent from three individuals with cystinosis and from six control subjects. Fibroblasts were cultivated in Eagle's minimal essential medium (22) supplemented with $15 \%$ fetal calf serum, $100 \mathrm{U} / \mathrm{ml}$ penicillin, 100 $\mu \mathrm{g} / \mathrm{ml}$ streptomycin, and $0.25 \mathrm{mg} / \mathrm{ml}$ Fungizone as described previously (13). All studies were performed on cells between the 6 th and 18th passages. When confluent, cells were harvested using $0.25 \%$ trypsin in Hank's balanced salt solution.

\section{DETERMINATION OF INTRACELLULAR CYSTINE}

This was done according to the method of States and Segal (19).

\section{TRANSPORT STUDIES}

Confluent fibroblasts were subcultured onto 20 12-mm no. I glass coverslips in Petri dishes for transport studies. The cultures were incubated at $37^{\circ}$ in an atmosphere of $5 \% \mathrm{CO}_{2}$ and $95 \%$ air and were fed with fresh medium at 2-to 3-day intervals and on the day before transport studies. In studies of transport parameters in different cell strains, cells of the same passage number were compared; celis were subcultured on the same day and were handled together thereafter in all experimental manipulations. On the day of transport studies, growth medium was removed by aspiration and the coverslips were washed twice with phosphate-buffered saline containing $\mathrm{CaCl}_{2}, 100 \mathrm{mg} /$ liter: $\mathrm{MgCl}_{2} \cdot 6 \mathrm{H}_{2} \mathrm{O}, 100 \mathrm{mg} /$ liter; and glucose $0.1 \%$ (PBS-G). Fresh PBS-G was then added and the attached cells were incubated at $37^{\circ}$ for $30 \mathrm{~min}$ before transport studies were initiated (4).

Substrate solutions for transport studies consisted of amino acids in the indicated concentrations in PBS-G at $37^{\circ}$. L- $\left[{ }^{35} \mathrm{~S}\right]$ Cystine, $250 \mathrm{mCi} / \mathrm{mmol}$, was obtained from Amersham/Searle (23). The radiochemical was subjected to high voltage paper electrophoresis at $\mathrm{pH} 1.9,4,000 \mathrm{~V}(50-75 \mathrm{ma})$, for $45 \mathrm{~min}$; radioactivity migrated as a single component with the same mobility as L-cystine; no radioactive impurities were detected. Coverslips at confluency were blotted dry and then dipped in the incubation medium with continuous agitation. At the end of the incubation period, the 
coverslip was rinsed by rapidly dipping through three containers of normal saline. The edge of the coverslip was then touched to filter paper and the coverslip was dropped into a scintillation vial, to which was added $10 \mathrm{ml} \mathrm{1:1} \mathrm{toluene-methyl-Cellosolve} \mathrm{with} 0.4 \%$ 2,5-diphenyloxazole (PPO) and 0.005\% p-bis-[2-(5-phenyloxazolyl)] -benzene (POPOP) (24). Radioactivity of the coverslips and of the substrate solution after incubation were measured in a liquid scintillation counter. In each experiment, three coverslips were dipped briefly in substrate solution and then rinsed and counted as above. These coverslips served as the "zero time" controls.

Distribution ratios (defined as the ratio of concentration of amino acid in intracellular fluid to concentration of amino acid in the substrate solution) were used as a measure of intracellular amino acid accumulation. Intracellular water was measured as space accessible to $\left[{ }^{14} \mathrm{C}\right]$ urea but not to $\left[{ }^{14} \mathrm{C}\right]$ inulin. Replicate coverslips from the same Petri dish were exposed to $\left[{ }^{14} \mathrm{C}\right]$ urea $(2-10 \mathrm{mCi} / \mathrm{mmol}(25))$ or $\left[{ }^{14} \mathrm{C}\right]$ inulin (inulin- $\left[{ }^{14} \mathrm{C}\right]$ carboxyl; $1-3$ $\mathrm{mCi} / \mathrm{g} \mathrm{(25))} \mathrm{for} 30 \mathrm{~min}$. The coverslips were removed, touched to filter paper, and counted for radioactivity. Protein was measured by the method of Lowry et al. (12) applied directly to cells on coverslips which had been well rinsed to remove growth medium. At least three coverslips from each dish were used for protein determination; variation in protein content per coverslip in each Petri dish was less than $5 \%$. As has been previously reported $(1,4)$, intracellular water space was directly proportional to protein content per coverslip. Because data obtained from Arrhenius plots indicated that nondiffusional processes were responsible for L-cystine uptake at both high and low L-cystine concentrations (see Results), uptake was not corrected for diffusion.

Accumulation of $\mathrm{L}-\left[{ }^{35} \mathrm{~S}\right]$ cystine by cystinotic and normal fibroblasts was determined at substrate concentrations of $0.004,0.010$, $0.020,0.040$, and $0.080 \mathrm{mM}$ over a 20 -min incubation period.

Inhibition of L-cystine uptake by amino acids was performed at 60 -sec incubation periods utilizing a wide variety of amino acids at $1 \mathrm{mM}$ concentration in the substrate solution. All amino acids were obtained from Sigma Chemical Company (26), and were Sigma grade. Serine, cystathionine, and homocystine contained no detectable cystine by thin layer chromatography.

\section{DETERMINATION OF INTRACELLULAR LABEL AFTER 60-SEC INCUBATION}

Forty-eight hours after subculture, fibroblasts were washed free of medium with PBS-G. PBS-G containing L- $\left[{ }^{35} \mathrm{~S}\right]$ cystine at concentrations of $0.004-0.150 \mathrm{mM}$ was then added to the monolayers. The cells were incubated at $37^{\circ}$ for $60 \mathrm{sec}$, after which the substrate solution was poured off and the cells were immersed in ice and rapidly cooled to a temperature of $4^{\circ}$. The cells were washed three times in ice-cold saline and then removed from the flasks by scraping with a rubber policeman in the cold. The cell suspensions were washed with ice-cold saline two additional times to remove any residual traces of substrate solution. PBS-G containing $20 \mathrm{mM} \mathrm{N}$-ethylmaleimide (NEM; Sigma), $0.5 \mathrm{ml}$, was then added to the cell pellet and the cells were freeze-thawed five times in Dry Ice. Three percent sulfosalicylic acid, $0.5 \mathrm{ml}$, was then added to the solution which was centrifuged at $20,000 \mathrm{rpm}$ in a 40 rotor of a Spinco model L ultracentrifuge for $30 \mathrm{~min}$. An aliquot of the clear supernatant solution was subjected to high voltage paper electrophoresis at $4000 \mathrm{~V}, \mathrm{pH} 1.9$ (50-75 ma), for $45 \mathrm{~min}$ for separation of amino acids. The paper was cut into $1-\mathrm{cm}$ strips and radioactivity was located by counting in a liquid scintillation counter. Standard solutions of L-cystine, L-cysteine-NEM, and glutathione-NEM were run simultaneously with the sample for determination of the positions of these known substances. Glutathione-NEM and L-cysteine-NEM were not well separated from one another by this procedure; both compounds, however, were readily distinguished from L-cystine.

\section{RESULTS}

CYSTINE CONTENT OF CYSTINOTIC AND NORMAL FIBROBLASTS

The mean intracellular content of free cyst(e)ine in skin fibroblasts of three patients with cystinosis was $5.16 \mathrm{nmol} / \mathrm{mg}$ protein (range: $4.70-5.39 \mathrm{nmol} / \mathrm{mg}$ protein), whereas cyst(e)ine content in cells of five control individuals was less than 1.0 $\mathrm{nmol} / \mathrm{mg}$ protein. The method as applied is specific for cyst(e)ine.

\section{TIME COURSE OF $\left[{ }^{35}\right.$ S]CYSTINE UPTAKE BY CONTROL AND} CYSTINOTIC FIBROBLASTS

The results of timed accumulation studies are illustrated in Figures 1 and 2. Two cystinotic cell lines were compared with two normal cell lines in paired experiments of L-cystine accumulation at $0.010,0.020,0.040$, and $0.080 \mathrm{mM}$ concentrations. At 0.010 $\mathrm{mM}$ substrate concentration, cystinotic and normal cells appeared to accumulate L-cystine at approximately the same rate. At 0.020 , 0.040 , and $0.080 \mathrm{mM} \mathrm{L}$-cystine concentrations, cystinotic cells appeared to accumulate more L-cystine than did normal cells over the time period studied, as has previously been reported (18). A representative experiment is illustrated in Figure 1. In contrast, when two cystinotic cell lines were compared with three normal cell lines in a total of nine paired experiments of L-cystine accumulation at $0.004 \mathrm{mM}$ concentration, cystinotic fibroblasts accumulated less L-cystine than did normal cells (mean uptake of cystinotic cells was $74 \% \pm 16 \%$ of normal at $20 \mathrm{~min}, p<0.02)$. A representative experiment is shown in Figure 2. At each substrate concentration, uptake was maximal during the first 2 min and then rapidly plateaued. Constant distribution ratios were not obtained by $30 \mathrm{~min}$. Therefore, all studies of the kinetics of cystine uptake were performed at an incubation time of $60 \mathrm{sec}$ in order to study initial rates of uptake.

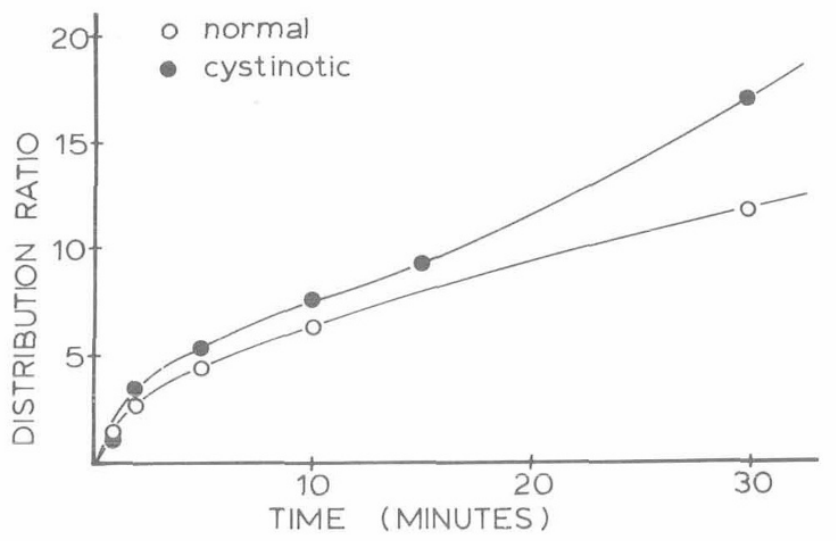

Fig. 1. Accumulation of $0.080 \mathrm{mM} \mathrm{L}-\left[{ }^{35} \mathrm{~S}\right]$ cystine in cystinotic and normal fibroblasts.

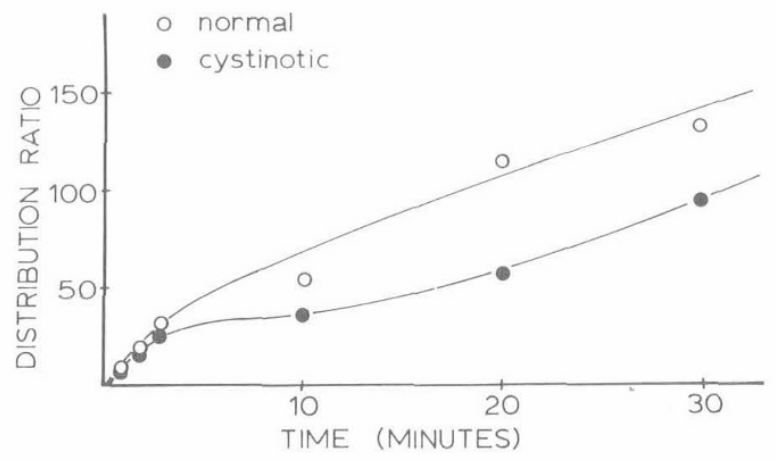

Fig. 2. Accumulation of $0.004 \mathrm{mM} \mathrm{L}-\left[{ }^{35} \mathrm{~S}\right]$ cystine in cystinotic and normal fibroblasts. 


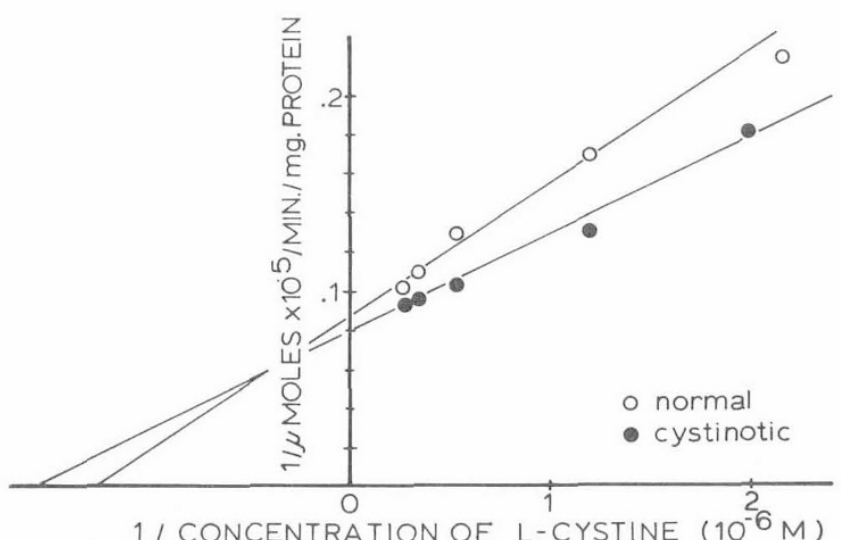

Fig. 3. Kinetics of L-cystine accumulation at low substrate concentration. The reciprocal of velocity of accumulation is plotted versus the reciprocal of initial substrate concentration for determination of the $\mathrm{K}_{\mathrm{m}}$ and $\mathrm{V}_{\max }$ of transport by means of the high affinity system.

\section{INITIAL RATE KINETICS}

The relationship of initial velocity of uptake to concentration of L-cystine was investigated over a concentration range of $0.3 \times$ $10^{-6}-0.8 \times 10^{-3} \mathrm{M}$ in normal and cystinotic cells. In both normal and cystinotic cells, two saturable processes of L-cystine accumulation with widely different substrate affinities were demonstrated. The first process (high affinity system) demonstrated saturation at approximately $0.004 \mathrm{mM}$ L-cystine concentration. When the reciprocal of velocity of uptake was plotted $v s$. the reciprocal of substrate concentration according to the method of Lineweaver and Burk (11), the apparent $\mathrm{K}_{\mathrm{m}}$ was calculated to be $0.00078 \mathrm{mM}$ in the normal cell line (range: $0.00040-0.0012$ in five experiments); the $\mathrm{V}_{\max }$ was $38 \mu \mathrm{mol} /$ liter cell water $\min$ (range: $28-56 \mu \mathrm{mol}$ / liter cell water $\min$ in five experiments). In the affected cell line, the $\mathrm{K}_{\mathrm{m}}$ was $0.00061 \mathrm{mM}$ (range: $0.00050-0.0011$ in five experiments) and the $V_{\max }$ was $41 \mu \mathrm{mol} /$ liter cell water $\mathrm{min}$ (range: $30-61$ in five experiments) (Fig. 3). The second process (low affinity system) appeared saturable at very high substrate concentrations. The apparent $\mathrm{K}_{\mathrm{m}}$ was $0.37 \mathrm{mM}$ L-cystine (range: $0.30-0.44 \mathrm{mM}$ in three experiments) and the $\mathrm{V}_{\max }$ was 0.74 $\mathrm{mmol} /$ liter cell water $\cdot \mathrm{min}$ (range: $0.52-0.80$ in three experiments) in both normal and affected cells (Fig. 4).

\section{EFFECT OF TEMPERATURE ON ACCUMULATION OF L-CYSTINE}

In order to determine the contribution of diffusion to L-cystine uptake by means of the high and low affinity transport systems, accumulation at $0.005 \mathrm{mM}$ and $0.5 \mathrm{mM}$ initial substrate concentrations at varying temperatures was investigated. In each instance, uptake velocity varied exponentially with absolute temperature (Fig. 5). The $Q_{10}$ at $0.5 \mathrm{mM}$ was 1.8 and the $Q_{10}$ at $0.005 \mathrm{mM}$ was $2.3\left(\mathrm{~T}^{\circ}+10=41^{\circ}\right)$. The rate of a diffusional process is directly proportional to absolute temperature whereas the rate of a chemical reaction varies exponentially with temperature. In general, the temperature coefficient $\left(Q_{10}=\right.$ the ratio of reaction rates at $\mathrm{T}+10^{\circ}$ and $\mathrm{T}^{\circ} \mathrm{C}$ ) in free diffusion in an aqueous solution is less than 1.5 (2). Thus, nondiffusional processes appeared to account for accumulation of L-cystine at both low and high substrate concentrations.

\section{INHIBITION STUDIES}

Inhibition of transport of L-cystine at an initial substrate concentration of $0.004 \mathrm{mM}$ was studied utilizing a wide variety of amino acids at $1 \mathrm{mM}$ concentration in the substrate solution (Table 1). L-Serine, L-homocystine, and L-cystathionine were found to partially inhibit L-cystine uptake, whereas L-glutamic acid, L-tryptophan, L-lysine, L-leucine, and L-methionine had no effect on the initial rate of L-cystine accumulation in normal or affected cells. Ascorbic acid at $0.57 \mathrm{mM}$ concentration also had no effect on the initial rate of L-cystine accumulation in normal or affected cells. L-Serine and L-homocystine and L-serine and L-cystathionine in combination appeared to exhibit an additive effect (Figs. 6 and 7), suggesting that transport of L-cystine at $0.004 \mathrm{mM}$ concentration may be a two-component system (3).

\section{EFFECT OF PRELOADING ON INITIAL UPTAKE VELOCITY}

The effect of high intracellular concentrations of a specific amino acid on initial uptake of L-cystine was investigated. Cells were preincubated with a solution containing a $1 \mathrm{mM}$ concentration of the specific amino acid suspended in PBS-G for $30 \mathrm{~min}$ at $37^{\circ}$. Control cells were preincubated in PBS-G. Initial uptake of L-cystine at $0.004 \mathrm{mM}$ concentration was determined. The results are shown in Table 2. Most of the amino acids tested resulted in

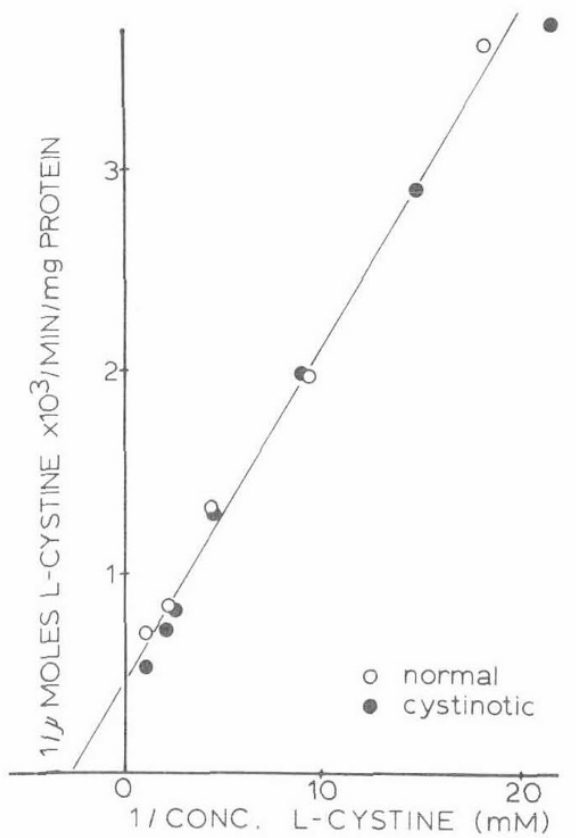

Fig. 4. Kinetics of L-cystine accumulation at high substrate concentration. The $K_{m}$ and $V_{\max }$ of transport by means of the low affinity system are determined as in Fig. 3.

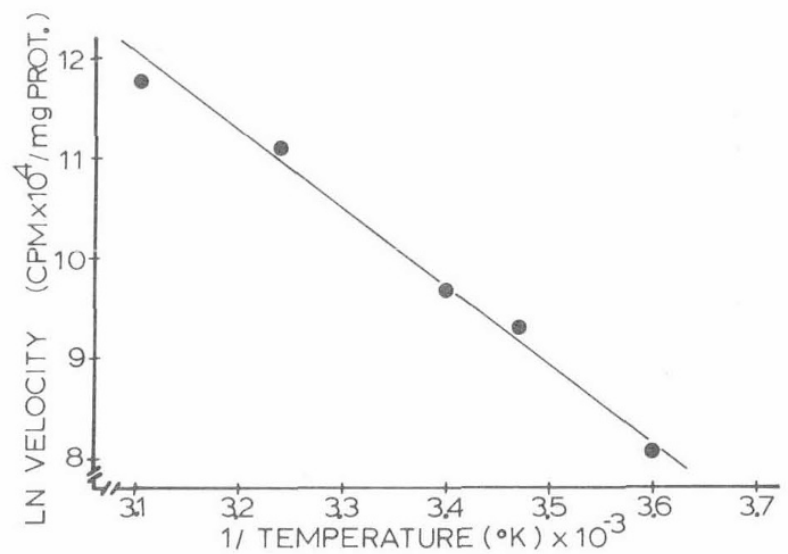

Fig. 5. Variation of velocity of L-cystine accumulation by the high affinity transport system with temperature. The natural logarithm of velocity of uptake is plotted $v s$. the reciprocal of absolute temperature in an Arrhenius plot; a linear relationship by this treatment indicates that the velocity of transport varies exponentially with temperature. A similar relationship was observed when the low affinity system was investigated. 
decreased uptake of approximately $50 \%$. In contrast, L-cystathionine enhanced uptake approximately $200 \%$, also suggesting the possibility of two transport systems with differing mechanisms of transport at this substrate concentration $(6,10)$.

\section{INTRACELLULAR FATE OF L-[ ${ }^{35}$ S]CYSTINE}

The fate of intracellular label after $60-\mathrm{sec}$ incubation at varying substrate concentrations is shown in Table 3. At each concentration tested, cystinotic cells retained more label as cystine. In addition, the degree of label remaining as cystine was unaffected by the substrate concentration.

\section{DISCUSSION}

These data indicate that uptake of L-cystine in both normal and cystinotic fibroblasts is a complex process involving more than a single nondiffusional transport system. The kinetic data suggest that at least two saturable processes with widely different substrate affinities mediate L-cystine uptake in skin fibroblasts. In addition, the transport process with high affinity for L-cystine may in itself be a two-component system, as suggested by the additive inhibitory effects of other neutral amino acids (3). This hypothesis is strengthened by the preincubation experiments. Preincubation

Table 1. Inhibition of $0.004 \mathrm{mM} \mathrm{L-cystine} \mathrm{accumulation} \mathrm{by} \mathrm{amino}$ acids in skin fibroblasts ${ }^{1}$

\begin{tabular}{lcc} 
& \multicolumn{2}{c}{ Distribution ratio at $60 \mathrm{sec}$} \\
\cline { 2 - 3 } \multicolumn{1}{c}{ Inhibitor } & Normal & Cystinotic \\
\hline None & 8.7 & 9.0 \\
L-Serine & 3.9 & 4.6 \\
L-Cystathionine & 3.2 & 4.0 \\
L-Homocystine & 4.1 & 3.9 \\
Glutathione (oxidized) & 7.8 & 8.0 \\
L-Lysine & 9.8 & 9.1 \\
L-Glutamic acid & 8.0 & 8.8 \\
L-Tryptophan & 10.0 & 9.9 \\
L-Methionine & 8.1 & 8.6 \\
L-Leucine & 7.1 & 8.0 \\
L-Cystine $(0.5 \mathrm{mM})$ & 0.93 & 1.1 \\
Ascorbic acid $(0.57 \mathrm{mM})$ & 9.4 & 9.3 \\
\end{tabular}

${ }^{1}$ All amino acids listed are at $1 \mathrm{mM}$ concentration unless otherwise specified.

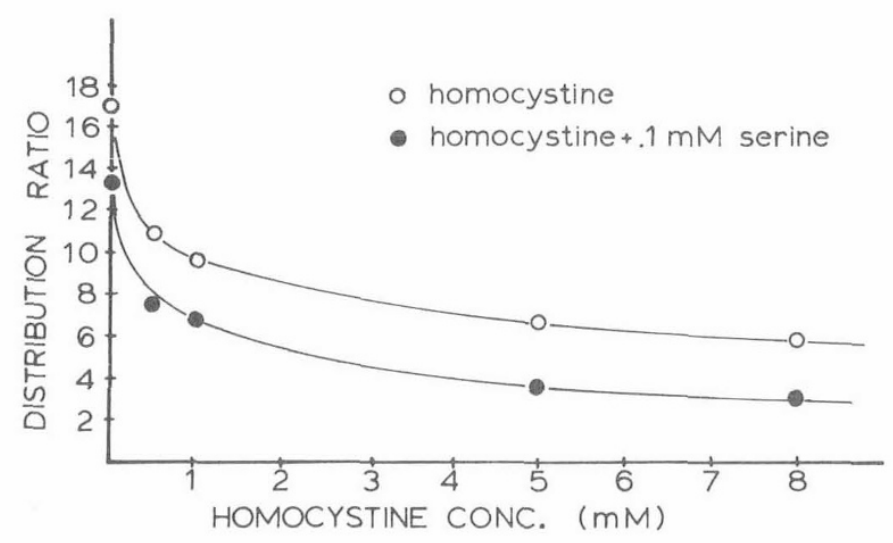

Fig. 6. Inhibition of accumulation of L-cystine at $0.004 \mathrm{mM}$ concentration by homocystine and homocystine plus serine. The open circles $(\mathrm{O})$ representL-cystine accumulation in the presence of varying homocystine concentrations; the closed circles $(-$ represent L-cystine accumulation in the presence of varying homocystine concentrations and $0.1 \mathrm{mM} \mathrm{L}$-serine.

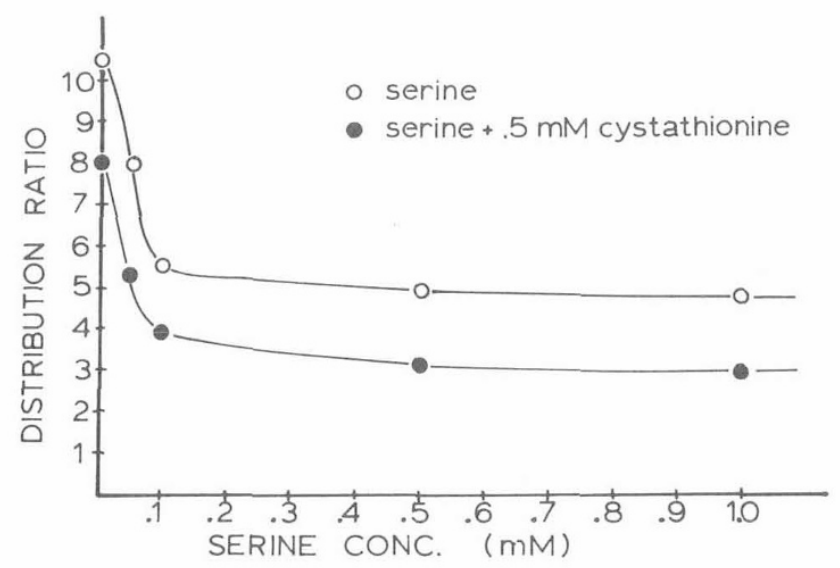

Fig. 7. Inhibition of accumulation of L-cystine at $0.004 \mathrm{mM}$ concentration by serine and cystathionine. The open circles $(\mathrm{O})$ represent L-cystine accumulation in the presence of varying serine concentrations; the closed circles (-) represent L-cystine accumulation in the presence of varying serine concentrations and $0.5 \mathrm{mM}$ cystathionine.

Table 2. Effect of preincubation on uptake of $0.004 \mathrm{mM}$ L-cystine by skin fibroblasts

$\%$ Uptake at $60 \mathrm{sec}$

Preincubation solution $\quad$ Normal Cystinotic

Phosphate-buffered saline $+0.1 \%$ glucose $\quad 100 \quad 100$

Serine, $1 \mathrm{mM}$

Homocystine, $1 \mathrm{mM}$

Reduced glutathione, $1 \mathrm{mM}$

$45 \quad 40$

Cystathionine, $1 \mathrm{mM}$

75

207

67

80

180

Table 3. Metabolic fate of ingested $L-\left[{ }^{35} S\right]$ cystine after 60 -sec incubation

\begin{tabular}{lcc}
\hline Cell line & $\begin{array}{c}\text { Concentration of } \\
\text { L-cystine, } \mathrm{mM}\end{array}$ & \% Label as L-cystine \\
\hline Normal & 0.004 & 23 \\
& 0.016 & 13 \\
& 0.032 & 19 \\
Cystinotic & 0.080 & 17 \\
& 0.004 & 56 \\
& 0.016 & 57 \\
& 0.032 & 50 \\
& 0.080 & 55 \\
\hline
\end{tabular}

with L-cystathionine enhances subsequent L-cystine uptake, whereas preincubation with other neutral amino acids depresses subsequent uptake, suggesting the possibility of two transport systems with differing mechanisms of transport at this substrate concentration $(6,10)$. Affinity constants and maximal velocities of initial uptake do not appear to be altered in cells derived from patients with cystinosis.

These findings are in sharp contrast to the work of States et al. (18), who reported an apparent $\mathrm{K}_{\mathrm{m}}$ of L-cystine uptake of 0.043 $\mathrm{mM}$ in both normal and cystinotic cells and an increased $\mathrm{V}_{\max }$ of uptake in cells derived from subjects with cystinosis. These differences may be explained when the methodology is reviewed. In the studies of States et al. (18), all kinetic investigations were performed at incubation periods of $20 \mathrm{~min}$, at which time, according to their data and ours, uptake is no longer linear with time. In addition, both studies indicate that metabolism of substrate has proceeded to a considerable degree by $20 \mathrm{~min}$. There- 
fore, the kinetic data previously reported cannot be considered to represent initial rates of transport but rather a combination of accumulation and metabolism.

Data presented in the present studies confirm the observation of States et al. (18) that L-cystine accumulation after a 20-min period is increased in cystinotic fibroblasts incubated in $0.080 \mathrm{mM}$ L-cystine. This effect appears to be concentration dependent, as indicated by the finding that accumulation of L-cystine after 20 $\mathrm{min}$ at $0.004 \mathrm{mM}$ concentration is decreased in cystinotic cells.

Groth and Rosenberg (5) investigated initial rates of accumulation of L-cystine and dibasic amino acids in cultivated fibroblasts derived from normal subjects and from individuals with cystinuria, an inherited disorder of renal and intestinal amino acid transport unreleated to cystinosis. The initial velocity of L-cystine uptake was studied over a range of L-cystine concentration of $0.025-0.50$ $\mathrm{mM}$, and an apparent affinity constant of $0.71 \mathrm{mM}$ was calculated. This finding is in good agreement with our "low affinity" transport system. Groth and Rosenberg (5) did not investigate L-cystine uptake at initial substrate concentrations below $0.025 \mathrm{mM}$ and, therefore, the additional concentrative and mediated transport systems described in this study were not observed.

Kroll and Schneider (9) have recently reported a decrease in free cystine content of cystinotic skin fibroblasts grown in tissue culture medium containing $0.57 \mathrm{mM}$ ascorbic acid. Ascorbic acid does not alter initial rates of cystine accumulation at $0.004 \mathrm{mM}$ initial substrate concentration; thus, the mechanism by which ascorbic acid decreases intracellular cystine does not appear to be related to an alteration in cystine transport by means of the high affinity, i.e., low substrate, transport systems.

The finding of more than a single transport system for uptake of L-cystine at varying substrate concentrations is of interest. Groth and Rosenberg (5) reported two energy-dependent, saturable processes for the transport of lysine and arginine in cultured fibroblasts. Hillman et al. (7) described three transport systems for transport of glycine in isolated mammalian renal tubules. Oxender and Christensen (14) described two distinct transport systems for uptake of neutral amino acids in ascites tumor cells. Thus, the finding of multiple systems capable of transporting a single biologic substrate is not unique. Our data indicate that L-cystine uptake in fibroblasts of patients with cystinosis proceeds at a normal rate by means of all transport systems currently shown to be present in normal cells. However, a defect in L-cystine transport cannot be totally excluded, as the biochemical basis for L-cystine accumulation in this disorder. A subtle alteration in one of these transport systems may yet be present or an additional, as yet undescribed, system may be absent or altered in cells of affected individuals. Alternatively, a defect in transport at the lysosomal membrane which is not expressed at the plasma membrane may account for accumulation within these organelles.

\section{SUMMARY}

Initial rates of accumulation of L-cystine were studied in cultivated skin fibroblasts of normai subjects and patients with cystinosis, a recessively inherited disorder characterized by lysosomal accumulation of L-cystine. Two transport systems were detected which appeared to mediate L-cystine uptake; a saturable low affinity transport system (apparent $\mathrm{K}_{\mathrm{m}}<0.37 \mathrm{mM}$ L-cystine; apparent $\mathrm{V}_{\max }=0.74 \mathrm{mmol} /$ liter cell water $\left.\cdot \mathrm{min}\right)$, and a high affinity transport system (apparent $\mathrm{K}_{\mathrm{m}} 0.001 \mathrm{mM}$; apparent $\mathrm{V}_{\max }$ $=38-41 \mu \mathrm{mol} /$ liter cell water. $\mathrm{min}$ ). Inhibition and preincubation studies with other neutral amino acids suggested that the high affinity system may itself be composed of more than a single component. All transport systems appeared to be present and unaltered in cells of patients with cystinosis. After prolonged incubation periods, accumulation of $0.080 \mathrm{mM}$ L-cystine was in- creased in cystinotic cells; this effect was not observed at 0.004 $\mathrm{mM}$ L-cystine concentration. After a $60-\mathrm{sec}$ incubation period, $20 \%$ of ingested L- $\left[{ }^{35} \mathrm{~S}\right]$ cystine remained in the oxidized form in normal cells while $50-60 \%$ of ingested $\mathrm{L}-\left[{ }^{35} \mathrm{~S}\right]$ cystine remained in the oxidized form in cystinotic cells. These studies indicate that transport of L-cystine by currently known systems is not altered in fibroblasts of patients with cystinosis.

\section{REFERENCES AND NOTES}

1. Booth, C. W., and Nadler, H. L.: Neutral amino acid transport in cultivated human skin fibroblasts. Proc. Soc. Exp. Biol. Med., 148: 277 (1975).

2. Christensen, H. N.: Biological Transport, pp. 12-15, (W. A. Benjamin, Inc., New York, 1962).

3. Christensen, H. N.: Some special kinetic problems of transport. Advan. Enzymol., 32: 1 (1969).

4. Foster, D. O., and Pardee, A. B.: Transport of amino acids by confluent and nonconfluent 3T3 and polyoma virus-transformed cells growing on glass coverslips. J. Biol. Chem., 244: 2675 (1969).

5. Groth, U., and Rosenberg, L. E.: Transport of dibasic amino acids, cystine and tryptophan by cultured human fibroblasts: Absence of a defect in cystinuria and Hartnup disease. J. Clin. Invest., 51: 2130 (1972).

6. Heinz, E., and Walsh, P. M.: Exchange diffusion, transport, and intracellular level of amino acids in Ehrlich carcinoma cells. J. Biol. Chem., 233: 1488 (1958).

7. Hillman, R. E., Albrecht, I., and Rosenberg, L. E.: Identification and analysis of multiple glycine transport systems in isolated mammalian renal tubules. J. Biol. Chem., 243: 5566 (1968).

8. Kaye, C., and Nadler, H. L.: Enzymic reduction of cystine and glutathione by cultivated skin fibroblasts of normal subjects and patients with cystinosis. J. Lab. Clin. Med (In press.)

9. Kroll, W. A., and Schneider, J. A.: Decrease in free cystine content of cultivated cystinotic fibroblasts by ascorbic acid. Science, 186: 1040 (1974).

10. Lin, E. C. C.: The molecular basis of membrane transport systems. In: L. I. Rothfield: Structure And Function of Biological Membranes, pp. 285-341 (Academic Press, New York, 1971).

11. Lineweaver, H., and Burk, D.: The determination of enzyme dissociation constants. J. Amer. Chem. Soc., 56: 658 (1934).

12. Lowry, O. H., Rosebrough, N. J., Farr, A. L., and Randall, R. J.: Protein measurement with the Folin phenol reagent. J. Biol. Chem., 193: 265 (1951).

13. Nadler, H. L., Inouye, T., Justice, P., and Hsia, D. Y.-Y.: Enzymes in cultivated human fibroblasts derived from patients with Down's syndrome (mongolism). Nature, 213: 1261 (1962).

14. Oxender, D. L., and Christensen, H. N.: Distinct mediating systems for the transport of neutral amino acids by the Ehrlich cell. J. Biol. Chem., 238: 3686 (1963).

15. Schneider, J. A., Bradley, K. H., and Seegmiller, J. E.: Transport and intracellular fate of cystine- ${ }^{35} \mathrm{~S}$ in leukocytes from normal subjects and patients with cystinosis. Pediat. Res., 2: 441 (1968).

16. Schulman, J. D., Bradley, K. H., Berexesky, I. K., Grimley, P. M., Dodson, W. E., and Al-Aish, M. S.: Biochemical, morphologic and cytogenetic studies of leukocytes growing in continuous culture from normal individuals and patients with cystinosis. Pediat. Res., 5: 501 (1971).

17. Seegmiller, J. E.: In: H. G. Hers and F. Van Hoof: Lysosomes and Storage Diseases, p. 485 (Academic Press, New York, 1973).

18. States, B., Harris, D., and Segal, S.: Uptake and utilization of exogenous cystine by cystinotic and normal fibroblasts. J. Clin. Invest., 53: 1003 (1974).

19. States, B., and Segal, S.: Quantitation of cyst(e)ine in human fibroblasts and separation of cysteinesulfinic acid, cysteic acid and taurine. Clin. Chim. Acta, 43: 49 (1973).

20. Teitze, J., Bradley, K. H., and Schulman, J. D.: Enzymic reduction of cystine by subcellular fractions of cultured and peripheral leukocytes from normal and cystinotic individuals. Pediat. Res., 6: 649 (1972).

21. Waterson, J. R., Winger, W. P., and Schmickel, R. D.: Cystine activation in altered cystinotic cells. A specific activity cysteinyl + RNA synthetase + RNA $A_{c y s}$ determination of the Michaelis-Menten constants for cystino-RNA synthetase. J. Clin. Invest., 54: 182 (1974).

22. Grand Island Biological Co., Grand Island, N.Y.

23. Arlington Heights, III.

24. Research Products International, Elk Grove Village, III.

25. New England Nuclear, Boston, Mass.

26. St. Louis, Mo.

27. Dr. H. L. Nadler is the Irene Heinz Given and John LaPorte Given Research Professor of Pediatrics.

28. These studies were supported by grants from The National Institutes of Health HD 00036 and HD 04252, The National Foundation-March of Dimes, The Kroc Foundation, and The Helen Fay Hunter Trust.

29. Requests for reprints should be addressed to: C. Kaye, M.D., Ph.D., Division of Genetics and Metabolism, Department of Pediatrics, Cook County Hospital, 700 S. Wood St., Chicago, Ill. 60612 (USA)

30. Accepted for publication January 14, 1976. 